\title{
Inhibition of miR-10a-5p suppresses cholangiocarcinoma cell growth through downregulation of Akt pathway
}

This article was published in the following Dove Press journal:

OncoTargets and Therapy

\author{
Lili Gao',* \\ Xiaoping Yang 2 ,* \\ Hao Zhang ${ }^{2}$ \\ Minghua $\mathrm{Yu}^{3}$ \\ Jianting Long ${ }^{4}$ \\ Tao Yang
}

'Center for Medical Research and Innovation, ${ }^{2}$ Department of General Surgery, ${ }^{3}$ Department of Medical Oncology, Shanghai Pudong Hospital, Fudan University Pudong Medical Center, Shanghai 201399, People's Republic of China; ${ }^{4}$ Department of Medical Oncology, The First Affiliated Hospital of Sun Yat-sen University, Guangzhou 510080, Guangdong Province, People's Republic of China

*These authors contributed equally to this work
Backgrounds: Cholangiocarcinoma (CCA) is epithelial cell malignancy with very poor prognosis. A lot of patients were diagnosed at advanced stage of CCA and no risk factors were identified. There are limited treatment options available for the management of CCA patients. It is urgent to develop effective targeted therapies for the treatment of CCA. miRNAs are small noncoding RNAs that negatively regulate the target genes. In this study, we investigated the role and mechanism of miR-10a-5p in CCA.

Methods: Human CCA cell lines (CCLP1 and SG-231) were transfected with miR-10a-5p mimic or miR-10a-5p inhibitor. qRT-PCR was performed to detect the miR-10a-5p level. Proliferation, colony formation, and apoptosis were analyzed. Luciferase reporter assay was used to explore the targeting of miR-10a-5p on PTEN. For in vivo tumorigenesis assay, CCLP1 cells with stable knockdown of miR-10a-5p or control CCLP1 cells were injected subcutaneously into the flank of the SCID mice and animals were monitored for tumor growth.

Results: miR-10a-5p expression was significantly upregulated in human CCA cell lines (CCLP1 and SG-231). Inhibition of miR-10a-5p significantly suppressed the proliferation and induced apoptosis in CCLP1 and SG-231. PTEN is a direct target of miR-10a-5p in CCA cells.

Conclusion: Inhibition of miR-10a-5p can decrease CCA cells growth by downregulation of Akt pathway. These results indicate that miR-10a-5p may serve as a potential target for the treatment of CCA and help to develop effective therapeutic strategies.

Keywords: miR-10a-5p, cholangiocarcinoma, PTEN, Akt, liver, proliferation

\section{Introduction}

Cholangiocarcinoma (CCA) is the second most common primary liver malignancy. CCA represents a diverse group of epithelial cell malignancy that develops along the biliary tract. ${ }^{2,3} \mathrm{CCA}$ are classified into intrahepatic CCA (iCCA), perihilar CCA (pCCA), and distal CCA (dCCA) depending on their site of origin. ${ }^{4}$ Different types of CCA have different features and require specific treatments. Primary sclerosing cholangitis is considered to be the principal risk factor for CCA. ${ }^{5}$ Other risk factors include hepatitis $\mathrm{C}$ virus, human immunodeficiency virus, liver cirrhosis, and diabetes. ${ }^{6}$ However, in most CCAs, no risk factors are identified. The incidence of ICC in the US continues to rise. Between 1973 and 2012, the reported US incidence of ICC increased from 0.44 to 1.18 cases per $100,000 .^{7}$ Patients with CCA often present symptoms with biliary obstruction or non-specific abdominal pain, a high proportion of patients were diagnosed at advanced stage of CCA.$^{8}$ At early stage, curative options are available in the form of surgical resection and/or liver transplantation. ${ }^{9}$ The most frequently used treatment modality is chemotherapy. Due to high rate of recurrence after liver 
transplantation, distant metastasis and invasion, as well as the chemoresistance, CCA patients represent a very poor prognosis. The average 5-year survival rate for CCA patients is $5 \%-10 \%{ }^{10}$ It is urgent to develop new specific effective targeted therapies for the treatment of CCA.

miRNAs are small noncoding RNAs which are short single-stranded molecules about 21-23 nucleotides in length. ${ }^{11}$ miRNAs regulate gene expression at post transcriptional level. miRNAs inhibit the target genes expression by binding to $3^{\prime}$ untranslated regions (3'UTRs) of target mRNAs which cause mRNA degradation and destabilization. ${ }^{12}$ miRNAs play important roles in a broad range of biological processes, such as embryonic development, ${ }^{13}$ apoptosis, ${ }^{14}$ stem cell differentiation, ${ }^{15}$ hematopoiesis, ${ }^{16}$ and immune response. ${ }^{17}$ Dysregulation of miRNA expression has been reported in cancer, including CCA. For example, miR-29a has emerged as a tumor suppressor, miR-29a level was found significantly decreased in both CCA tissues and tumor cell lines. ${ }^{18}$ miR-34a was rhythmically expressed in CCA cells. Inhibition of miR-34a decreased proliferation, migration, and invasion in CCA cells. ${ }^{19}$ miR-21 and miR-221 levels significantly upregulated in CCA serum. Circulating plasma levels of miR-21 and miR-221 can serve as a diagnostic and prognostic biomarkers for CCA. ${ }^{20,21}$

miR-10 family including miR-10a and miR-10b has attracted attention because of its conservation and the position of the miR-10 genes within the Homeobox (HOX) clusters. $^{22}$ Hox genes are a group of evolutionarily conserved genes that encode a class of important transcription factors that regulate early developmental morphogenetic processes and continue to be expressed into adulthood. ${ }^{23}$ Hox genes organized into four distinct clusters. These clusters, labeled HOXA, HOXB, HOXC, and HOXD, are located on chromosomes 7p14, 17q21, 12q13, and 2q31.23 miR-10a was located within the HOX B cluster on 17q21 and miR-10b was located at HOX D cluster $2 \mathrm{q} 31 .{ }^{24} \mathrm{miR}-10$ family members are deregulated in numerous types of cancers including uterine sarcomas, ${ }^{25}$ breast cancer, ${ }^{26}$ and hepatocellular carcinoma (HCC). ${ }^{27} \mathrm{miR}-10 \mathrm{a}$ has been reported to be associated with liver regeneration, ${ }^{28}$ regulates human mesangial cells proliferation and chemokine expression by targeting IL-8. ${ }^{29}$ Plasma miR-10a levels were decreased in patients with coronary artery disease (CAD) and negatively associated with the presence and severity of CAD. ${ }^{30}$ miR-10a serves as a switch to control miR-10a-NF-kB regulatory circuit that promotes the excessive secretion of NF- $\kappa \mathrm{B}$-mediated inflammatory cytokines and the proliferation and migration of fibroblast-like synoviocytes of rheumatoid arthritis (RA). ${ }^{31}$ miR-10a-5p is overexpressed in human pancreatic ductal adenocarcinoma (PDAC) and acts as an oncogene to promote the metastatic behavior of PDAC cells. ${ }^{32}$ Abnormal high expression of miR-10a was also found in patients with acute myeloid leukemia (AML). miR-10a promotes proliferation of immature blood progenitors and repression of mature blood cell differentiation and maturation in AML. ${ }^{33}$

The expression of miR-10 was upregulated in CCA. ${ }^{34}$ However, the function of miR-10a-5p in CCA is largely unknown. In the present study, we explored the role of miR-10a-5p in CCA. We found that PTEN is a direct target of miR-10a-5p in CCA cell lines. Inhibition of miR-10a-5p suppressed proliferation and promoted apoptosis in CCA cells through downregulation Akt pathway.

\section{Methods \\ Cell culture}

Human intrahepatic bile duct epithelial cell line HIBEC was obtained from American Type Culture Collection (ATCC, Manassas, VA, USA). Human CCA cell lines CCLP1 and SG-231 were obtained from Cell Bank of Chinese Academy of Sciences (Shanghai, People's Republic of China). Cells were cultured in Dulbecco's Modified Eagle's Medium (DMEM) containing 10\% FBS, L-glutamine, and antibiotics (100 units $/ \mathrm{mL}$ penicillin and $100 \mu \mathrm{g} / \mathrm{mL}$ streptomycin). All cells were maintained in a $37^{\circ} \mathrm{C}$ humidified incubator with $5 \% \mathrm{CO}_{2}$.

\section{Transfections}

CCLP1 and SG-231 cells were seeded in six-well plate and transfected with scramble control or miR-10a-5p mimic or miR-10a-5p inhibitor GenePharma (Shanghai, People's Republic of China) using Oligofectamine reagent (Thermo Fisher Scientific, Waltham, MA, USA) according to the manufacturer's instructions. Final concentration of scramble or miR-10a-5p mimic or miR-10a-5p inhibitor is $100 \mathrm{nM}$. At the indicated time point, cells samples were collected.

\section{qRT-PCR}

Total RNA was extracted from cells using Trizol (Thermo Fisher Scientific). Reverse transcription was performed using the miScript RT Kit (TaKaRa, Dalian, People's Republic of China). qRT-PCR was performed using miScript SYBR Green PCR Kit (Qiagen NV, Venlo, the Netherlands) on a C1000 thermal cycler (Bio-Rad Laboratories Inc., Hercules, CA, USA). The primers of miR-10a-5p and U6 were obtained from Qiagen NV. U6 was used as an internal control. 


\section{Cell proliferation assay}

Proliferation assays were conducted using WST-1 assay (Beyotime, Shanghai, People's Republic of China). After CCLP1 and SG-231 cells were transfected with miR-10a-5p mimic or miR-10a-5p inhibitor or scramble control for 6 hours, cells were seeded in 96-well plates (2,000 cells/well). At $0,24,48$, and 72 hours, culture medium was removed and $100 \mu \mathrm{L}$ fresh medium containing $10 \mu \mathrm{L}$ of WST- 1 reagents was added into the wells. After 2-3 hours, the absorbance was measured at $450 \mathrm{~nm}$ by using ELISA Microplate Reader (Biocompare, San Francisco, CA, USA).

\section{Western blot analysis}

Total protein was extracted from cells using a protein extraction kit (Beyotime). Protein concentrations were measured using the BCA Protein Assay Kit (Beyotime). Protein fractions were separated on SDS-PAGE gel electrophoresis (Bio-Rad Laboratories Inc.) and transferred to a nitrocellulose membrane (Bio-Rad Laboratories Inc.). After blocking in 5\% skim milk in PBS for 1 hour at room temperature, the membranes were incubated overnight at $4^{\circ} \mathrm{C}$ with primary antibodies. Primary antibodies against PARP, cleaved caspase-3, PTEN, p-Akt (ser473), and Akt were obtained from Cell Signaling Technology (Danvers, MA, USA). Primary antibody against $\beta$-actin was obtained from Abcam (Cambridge, MA, USA). Secondary antibodies IRDye800CW Goat anti-Mouse IgG and IRDye800CW Goat anti-Rabbit IgG were obtained from LI-COR (LI-COR Biosciences, Lincoln, NE, USA). Western bolt images were detecting by using Li-COR Odyssey 9120 Imaging System (LI-COR Biosciences).

\section{Luciferase reporter assays}

PTEN 3'-UTR was obtained from GeneCopoeia (Rockville, MD, USA). We mutated two nucleotides of the PTEN 3'-UTR by using Site-Directed Mutagenesis kit (Stratagene, Shanghai, People's Republic of China). These vectors also express the Renilla luciferase serving as internal controls for the dual-luciferase assay. CCLP1 and SG231 were cotransfected with miR-10a-5p mimic $(100 \mathrm{nM})$ or scramble (100 nM) with PTEN 3'-UTR or its mutant (Mut) using lipofectamine 2000 transfection reagent (Thermo Fisher Scientific). After 48 hours of transfection, the luciferase activity was measured using the dual luciferase reporter assay kit (Promega Corporation, Madison, WI, USA).

\section{Colony formation assay}

Lentiviral plasmid vector expresses miR-10a-5p inhibitor (LV-miR-10-5p-inhibitor) and scramble control lentivirus vector (LV-con) were obtained from ABM Industries Inc. (New York, NY, USA). We established CCLP1 cell line with stable knockdown of miR-10a-5p by transfecting cells with LV-miR-10-5p-inhibitor. The control CCLP1 cells were transfected with LV-con. Cells were seeded in $10 \mathrm{~cm}$ dishes at 2,000 cells/dish and cultured for 14 days. After fixation with methanol for 20 minutes, the colonies were stained with $0.1 \%$ crystal violet.

\section{Mouse xenograft model}

For tumorigenesis assays, 6 weeks old, male SCID mice were purchased from Wei Tong Li Hua Experimental Animal Technology Co., Ltd (Beijing, People's Republic of China) $(\mathrm{n}=3)$. In total, $1 \times 10^{6} \mathrm{miR}-10 \mathrm{a}-5 \mathrm{p}$ stable knockdown CCLP1 cells (LV-miR-10a-5p-inhibitor) or control CCLP1 cells (LV-con) were injected subcutaneously into the flank of the mice. Mice were observed for 30 days for tumor formation. Tumor diameters are measured with digital calipers, and the tumor volume in $\mathrm{mm}^{3}$ is calculated by the formula: Volume = $(\text { width })^{2} \times$ length $\div 2$. All animal studies were approved by the Ethics Committee of Fudan University Pudong Medical Center. The handling of the mice and all experimental procedures were carried out in strict accordance with Fudan University Guidelines for the Care and Use of Laboratory Animals.

\section{Statistical analysis}

Data represent the mean \pm SD. Experiments were repeated at least three times. Statistical analysis was performed using GraphPad Prism (version 5.0, GraphPad Software, Inc., La Jolla, CA, USA). One-way ANOVA along with Bonferroni adjustment and Student's $t$-test were used to evaluate the differences between groups. A $P$-value $<0.05$ was considered statistically significant.

\section{Results}

\section{Inhibition of miR-10a-5p suppresses proliferation and promotes apoptosis in CCA cells}

We evaluated the expression of miR-10a-5p in human intrahepatic bile duct epithelial cell line HIBEC and human CCA cell lines (CCLP1 and SG-231) by qRT-PCR analysis. Results showed that miR-10a-5p was upregulated significantly in CCA cells compared with HIBEC (Figure 1A). To evaluate the role of miR-10a-5p on CCA cells growth, human CCA cell lines CCLP1 and SG-231 were transfected with miR$10 \mathrm{a}-5 \mathrm{p}$ mimic or miR-10a-5p inhibitor or scramble control. The expression of miR-10a-5p was determined by qRT-PCR. As shown in Figure 1B, compared with scramble control, 

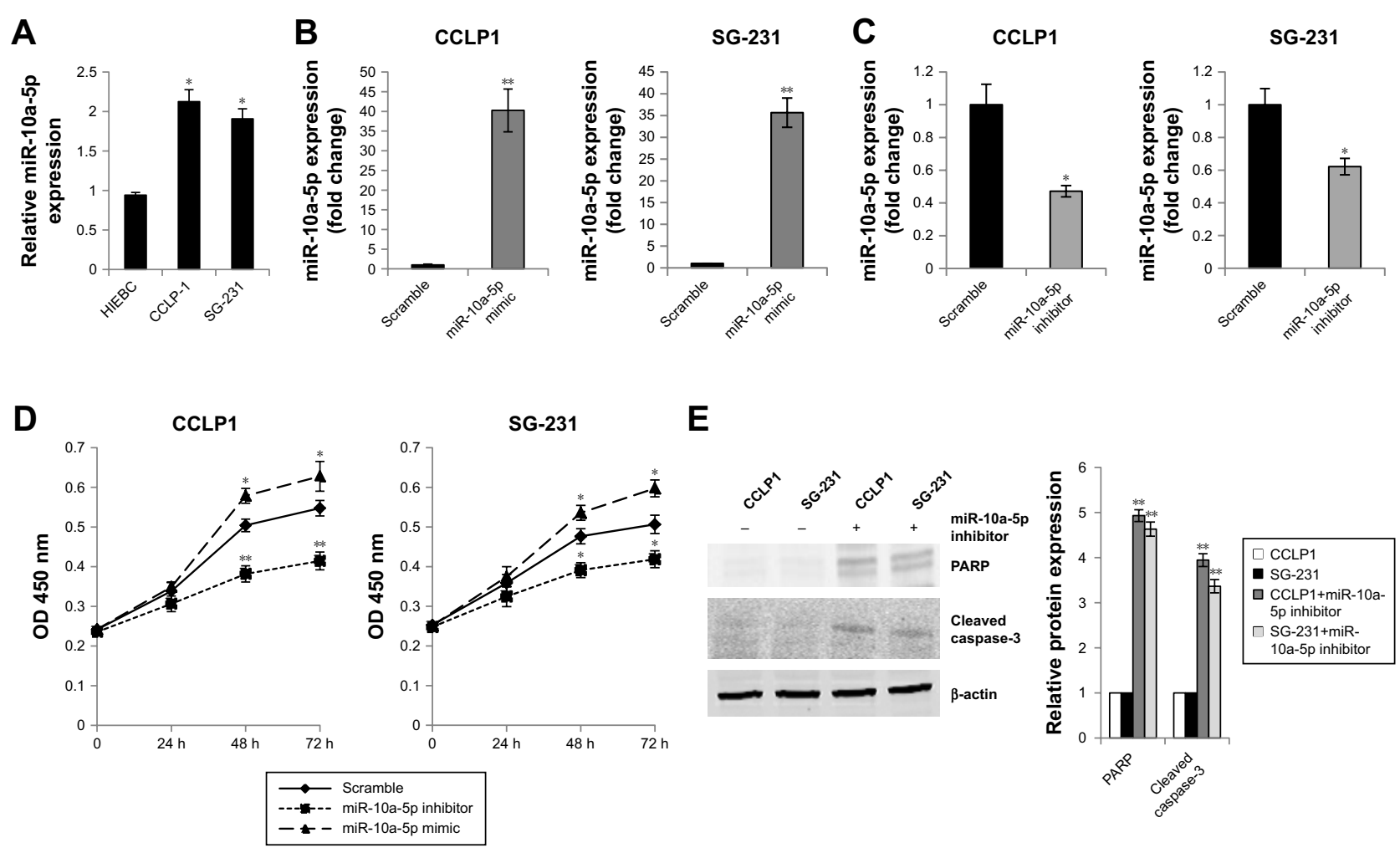

E

Figure I Inhibition of miR-10a-5p suppresses CCA cell proliferation and induces apoptosis in vitro.

Notes: (A) The levels of miR-10a-5p in human intrahepatic bile duct epithelial cell line HIBEC and human CCA cell lines (CCLPI and SG23I) were determined by qRT-PCR analysis. (B) miR-10a-5p expression was determined by qRT-PCR in CCLPI and SG-23I cells post transfection of miR-I0a-5p mimic or scramble control for 72 hours. (C) miR-10a-5p expression was determined by qRT-PCR in CCLPI and SG-23I cells post transfection of miR-10a-5p inhibitor or scramble control for 72 hours. (D) The proliferation of CCLPI and SG-23I cells was measured by using WST-I analysis. (E) Western blot analysis of the protein levels of PARP and cleaved caspase-3. $\beta$-actin was used as an internal control. Quantifications of relative protein levels are shown at the right panel. Data were expressed as mean \pm SD. $* P<0.05$, $* * P<0.01$.

Abbreviation: CCA, cholangiocarcinoma.

transfection of miR-10a-5p mimic for 72 hours led to a dramatic increase expression of miR-10a-5p in both CCLP1 and SG231 cells, whereas transfection of miR-10a-5p inhibitor for 72 hours led to a significant inhibition of the miR-10a-5p level in these cells (Figure 1C). Cell viability was measured using WST-1 assay. As shown in Figure 1D, upregulated miR-10a-5p level by miR-10a-5p mimic significantly increased the proliferation in both of CCLP1 and SG-231 cells, whereas a significant decrease in cell viability was detected when cells transfected with miR-10a-5p inhibitor compared with scramble control. Western blot analysis revealed that the cleaved PARP and cleaved caspase-3 were significantly increased in CCLP1 and SG-231 cells transfected with miR-10a-5p inhibitor (Figure 1E). These results indicated that miR-10a-5p promoted CCA cells proliferation, while inhibition of miR-10a-5p suppressed cell growth and induced apoptosis in CCA cells.

\section{PTEN is a direct target of miR-10a-5p in CCA cells}

To explore the tumor suppressive mechanism of miR-10a- $5 p$ inhibition, the potential target genes of miR-10a-5p were analyzed using miRNA target prediction programs TargetScan (http://www.targetscan.org). There are 287 transcripts with conserved sites, containing a total of 302 conserved sites and 99 poorly conserved sites. The predicted targets of human miR-10a-5p are shown in Table S1. We found that there was a predicted miR-10a-5p binding site in the $3^{\prime}$-UTR of PTEN (PTEN, phosphatase, and tensin homologue deleted on chromosome ten) (Figure 2A). To determine whether PTEN was regulated by miR-10a-5p, CCLP1 and SG-231 cells were transfected with miR-10a-5p inhibitor, Western blot analysis showed that inhibition of miR-10a-5p significantly upregulated the protein levels of PTEN (Figure 2B) and decreased the expression of p-Akt (ser473) (Figure 2C). To further verify whether PTEN is a direct target of miR-10a-5p, we generated PTEN reporter construct containing 3'-UTR with mutations of miR-10a-5p binding site (indicated in Figure 2A). CCLP1 and SG-231 cells were transfected with wild type or Mut PTEN 3'-UTR and miR-10a-5p mimic, luciferase reporter assay showed that miR-10a-5p mimic remarkably decreased the $3^{\prime}$-UTR luciferase reporter activity of PTEN, this effect was abolished when miR-10a-5p binding site was mutated (Figure 2D). These findings 




B
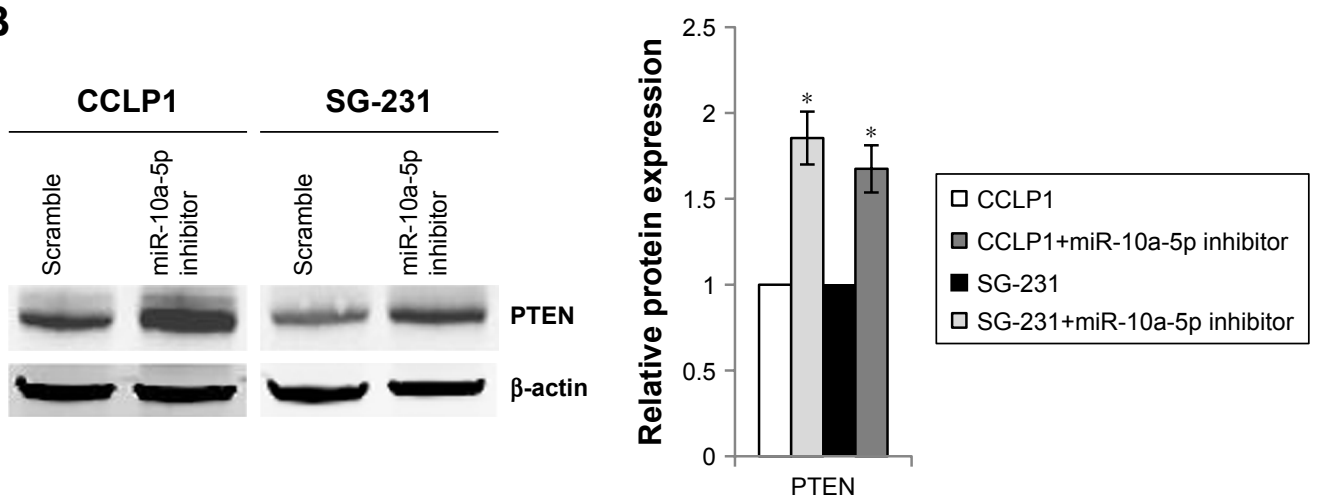

C
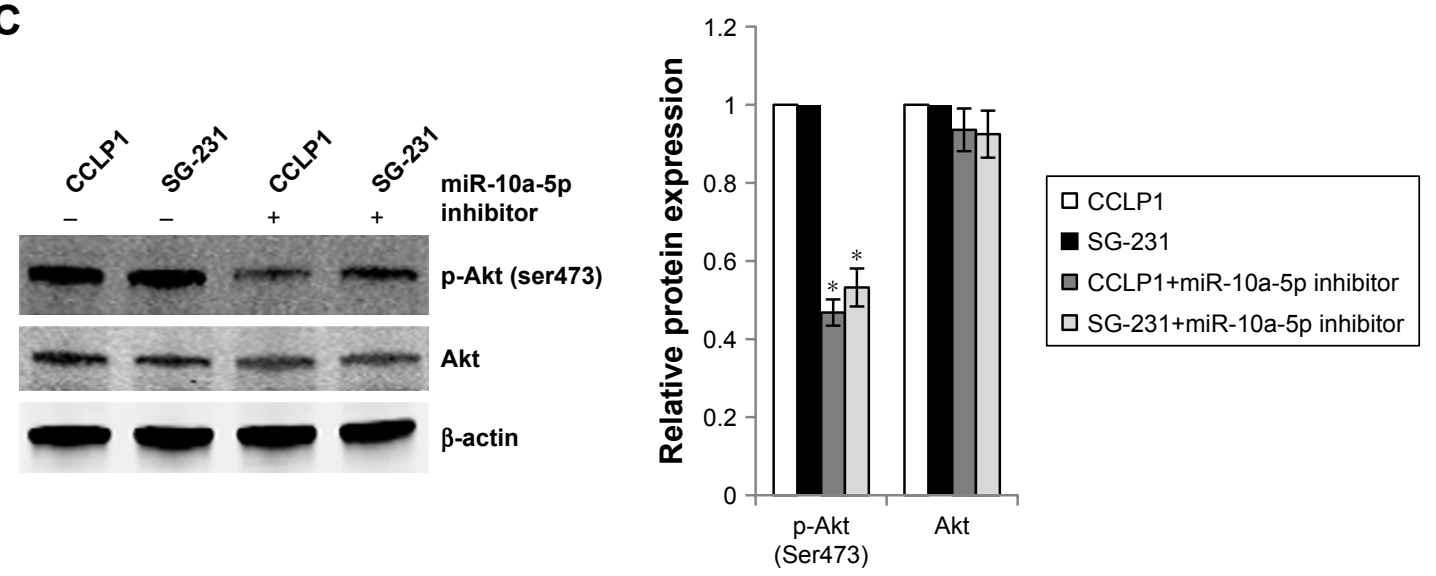

D

CCLP1
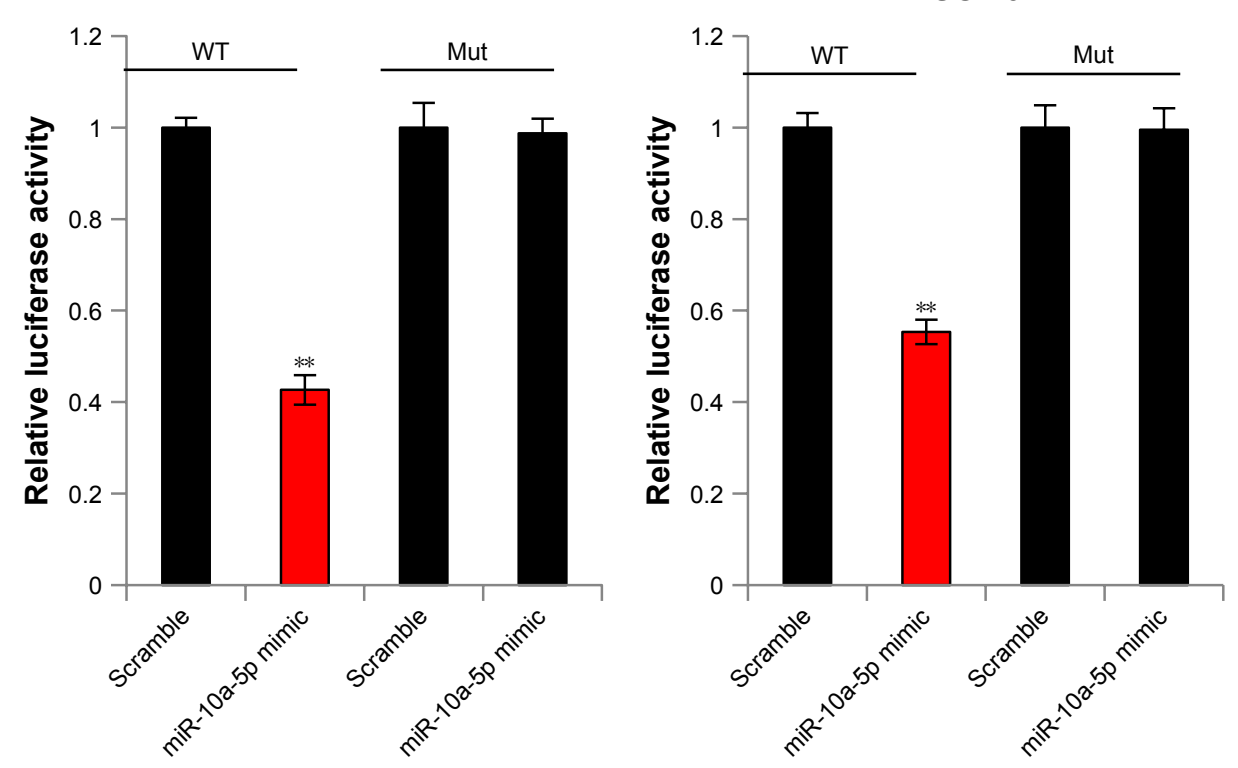

Figure 2 PTEN was a direct target of miR-10a-5p in CCA.

Notes: (A) The $3^{\prime}$-UTR of PTEN contained a predicted miR-10a-5p binding site. Mutations were generated on the two nucleotides of the PTEN $3^{\prime}-\mathrm{UTR}$ as indicated. (B) CCLPI and SG-23I were transfected with miR-10a-5p inhibitor or scramble control for 48 hours, protein levels of PTEN were determined by Western blot analysis. Quantifications of relative protein levels are shown at the right panel. (C) Western blot analysis of p-Akt (ser473) and total Akt. Quantifications of relative protein levels are shown at the right panel. (D) Relative luciferase activity in CCLPI and SG-23I cells co-transfected with WT or Mut PTEN 3'-UTR and miR-I0a-5p mimic or scramble control. Red bar indicates statistical difference. Data were expressed as mean $\pm S D$. $* P<0.05, * * P<0.01$.

Abbreviations: CCA, cholangiocarcinoma; 3'-UTR, 3'-untranslated regions; Mut, mutation; WT, wild type. 


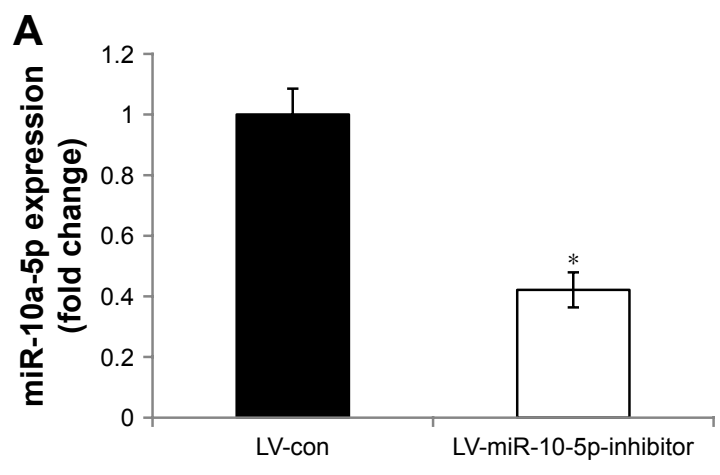

C

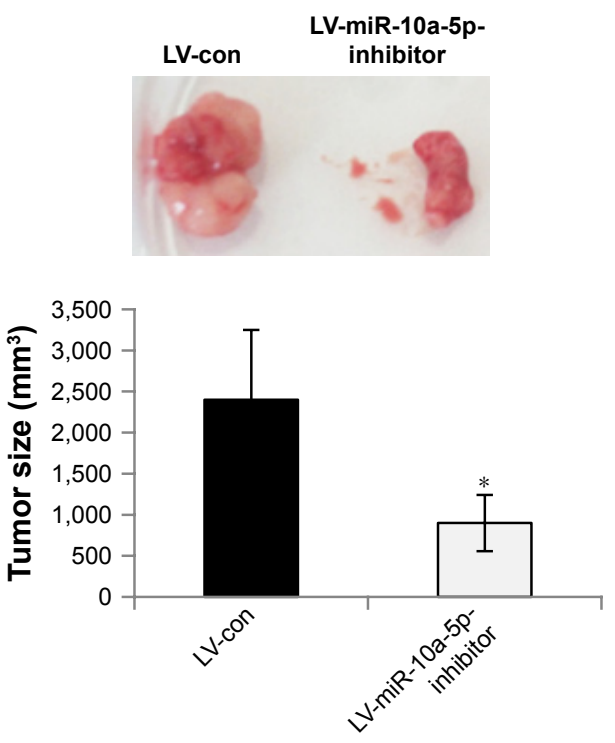

B

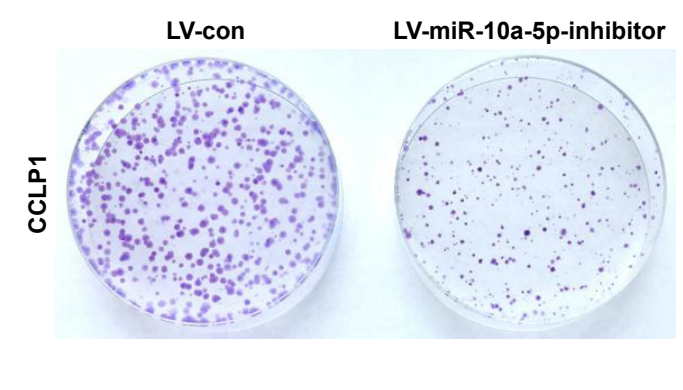

D
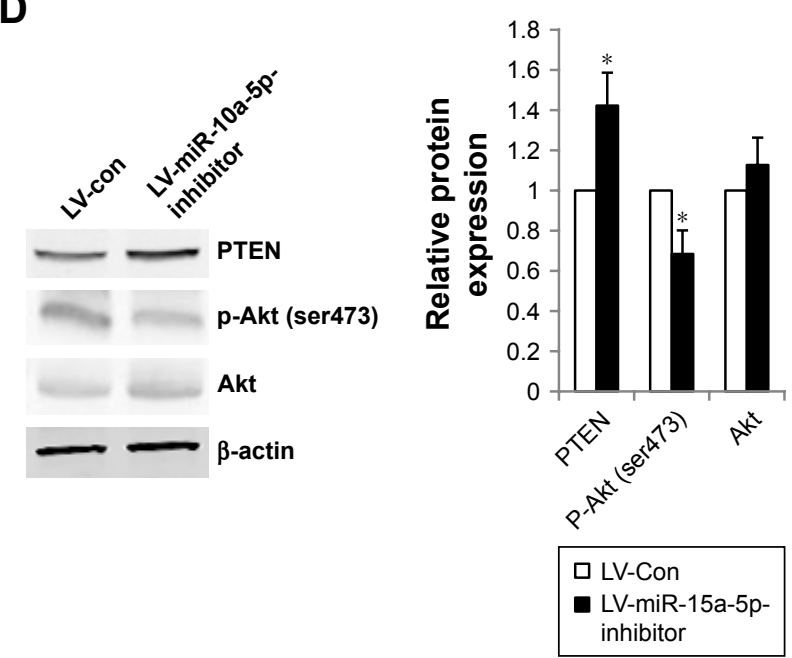

Figure 3 Inhibition of miR-10a-5p reduces tumor burden in vivo.

Notes: (A) miR-10a-5p expression was determined by qRT-PCR in CCLPI cells with stable knockdown of miR-10a-5p (LV-miR-I0a-5p-inhibitor) and control cells (LVcon). (B) Representative images of colony formation. (C) Representative image of tumors excised from LV-miR-I0a-5p-inhibitor group and LV-con group (upper panel). Volume of xenograft tumors (lower panel). (D) Western blot analysis of PTEN, p-Akt (ser473), and total Akt in miR-I0a-5p-inhibited and control xenograft tumor tissues. Quantifications of relative protein levels are shown at the right panel. Data were expressed as mean \pm SD. $* P<0.05$.

suggested that PTEN was a direct target of miR-10a-5p in CCA cells.

\section{Inhibition of miR-10a-5p suppresses CCA growth in SCID mice}

To further evaluate the effects of miR-10a-5p on CCA growth in vivo, we generated CCLP1 cells with stable knockdown of miR-10a-5p. CCLP1 cells were transfected with LV-mir-10a-5p-inhibitor or LV-con. As shown in Figure 3A, the downregulation of miR-10a-5p was confirmed by qRT-PCR. Knockdown of miR-10a-5p led to a significantly decreased colony formation in CCLP1 cells compared with control cells (Figure 3B). CCLP1 cells with stable knockdown of miR-10a-5p and control cells were injected subcutaneously into the flank of SCID mice to establish a xenograft model. Compared with the control group, knockdown of miR-10a-5p resulted in a significant reduction of tumor size and tumor volume (Figure 3C). Western blot analysis of the tumor tissues confirmed upregulated PTEN and decreased p-Akt (ser473) in miR-10a-5p knockdown tumors (Figure 3D). Taken together, these results suggested that inhibition of miR-10a-5p played an important role suppressed CCA cell proliferation.

\section{Discussion}

CCA is an aggressive tumor with very poor prognosis. The majority of patients present with unresectable disease and have a survival of less than 12 months following diagnosis. ${ }^{35}$ It is crucial to understand the pathogenesis of CCA, find out the effective, targeted, individualized therapies, and improve the quality of patient's life. In our study, we investigated the effect of miR-10a-5p on CCA cells proliferation in vitro and in vivo. We found that overexpression of miR-10a-5p promoted CCA cells proliferation, whereas inhibition of miR-10a-5p suppressed proliferation and induced apoptosis in CCA cells. In a mouse xenograft model, inhibition of 
miR-10a-5p significantly suppressed tumorigenicity. PTEN is a direct target of miR-10a-5p in CCA cells. Inhibition of miR-10a-5p led to the downregulation of Akt pathway. miRNA expression has been reported to be involved in tumor progression and prognosis, including CCA. ${ }^{36}$ It has been reported that overexpression of miR-10a-5p promoted the migration and invasion of human HCC cell lines (QGY7703 and HepG2) in vitro but suppressed metastasis in vivo. ${ }^{37}$ EphA4 (Eph tyrosine kinase receptor) was identified as the direct target of miR-10a. miR-10a promotes HCC cell migration and invasion through targeting EphA4, thereby regulating epithelial-mesenchymal transition and cell adhesion. ${ }^{37}$ Downregulation of miR-10a-5p has been shown to promote proliferation and restricts apoptosis via targeting T-box transcription factor 5 (TBX5) in inflamed synoviocytes. ${ }^{38}$ In our study, we found that inhibition of miR-10a-5p suppressed CCA cells proliferation through regulating PTEN-Akt pathway.

Akt pathway has been well established as an important signaling intermediate controlling cell survival, growth, proliferation, and other cellular processes. ${ }^{39}$ Activation of Akt pathway is an important survival pathway activated in cancer. Increased activation of AKT signaling was reproducibly observed in both CCA cell lines and CCA tissues. ${ }^{40}$ PTEN is a tumor suppressor and is a major negative regulator of the Akt signaling pathway. PTEN can be regulated by posttranslational modifications that include oxidation, acetylation, phosphorylation, ubiquitination, and proteolytic cleavage and by protein-protein interactions. ${ }^{41}$ PTEN can also be regulated by miRNAs. miRNAs may function as either oncogenes or tumor suppressors depending on their downstream targets. ${ }^{42}$ For example, miR-21 contributes both HCC and CCA growth by targeting PTEN. ${ }^{43,44}$ miR-221 ${ }^{45}$ and miR-17-92 cluster $^{46}$ promote CCA growth by targeting PTEN. In our study, we found that PTEN is a direct target of miR-10a-5p in CCA cells. Inhibition of miR-10a-5p promotes apoptosis in CCA cells through regulating PTEN.

Increasing evidences have shown that miRNAs are potential targets for human cancer treatment. ${ }^{47}$ Our study provided insight into the mechanism of inhibition of miR-10a-5p suppressed CCA cells proliferation. miR-10a-5p may be serve as a potential target for CCA. These findings may help to better understand the tumorigenesis of CCA and develop effective therapeutic strategies.

\section{Acknowledgment}

The work was financially supported by National Natural Science Foundation of China (grant nos 81572518 and $81372750)$ to TY.

\section{Disclosure}

The authors report no conflicts of interest in this work.

\section{References}

1. Blechacz B, Gores GJ. Cholangiocarcinoma: advances in pathogenesis, diagnosis, and treatment. Hepatology. 2008;48(1):308-321.

2. Razumilava N, Gores GJ. Cholangiocarcinoma. Lancet. 2014; 383(9935):2168-2179.

3. Ko KS, Peng J, Yang H. Animal models of cholangiocarcinoma. Curr Opin Gastroenterol. 2013;29(3):312-318.

4. Razumilava N, Gores GJ. Classification, diagnosis, and management of cholangiocarcinoma. Clin Gastroenterol Hepatol. 2013;11(1): 13.e1-21.e1

5. Vogel A, Wege H, Caca K, Nashan B, Neumann U. The diagnosis and treatment of cholangiocarcinoma. Dtsch Arztebl Int. 2014;111(44): 748-754.

6. Shaib YH, El-Serag HB, Davila JA, Morgan R, McGlynn KA. Risk factors of intrahepatic cholangiocarcinoma in the United States: a casecontrol study. Gastroenterology. 2005;128(3):620-626.

7. Saha SK, Zhu AX, Fuchs CS, Brooks GA. Forty-year trends in cholangiocarcinoma incidence in the U.S.: intrahepatic disease on the rise. Oncologist. 2016;21(5):594-599.

8. Najran P, Lamarca A, Mullan D, et al. Update on treatment options for advanced bile duct tumours: radioembolisation for advanced cholangiocarcinoma. Curr Oncol Rep. 2017;19(7):50.

9. Qureshi K, Jesudoss R, Al-Osaimi AM. The treatment of cholangiocarcinoma: a hepatologist's perspective. Curr Gastroenterol Rep. 2014; 16(10):412.

10. Strand DS, Cosgrove ND, Patrie JT, et al. ERCP-directed radiofrequency ablation and photodynamic therapy are associated with comparable survival in the treatment of unresectable cholangiocarcinoma. Gastrointest Endosc. 2014;80(5):794-804.

11. Felekkis K, Touvana E, Stefanou C, Deltas C. microRNAs: a newly described class of encoded molecules that play a role in health and disease. Hippokratia. 2010;14(4):236-240.

12. Fang $Z$, Rajewsky N. The impact of miRNA target sites in coding sequences and in 3’UTRs. PLoS One. 2011;6(3):e18067.

13. Liu Q, He H, Zeng T, Huang Z, Fan T, Wu Q. Neural-specific expression of miR-344-3p during mouse embryonic development. $J$ Mol Histol. 2014;45(4):363-372.

14. Kim JS, Choi DW, Kim CS, et al. MicroRNA-203 induces apoptosis by targeting Bmi-1 in YD-38 oral cancer cells. Anticancer Res. 2018; 38(6):3477-3485.

15. Hu T, Chong Y, Lu S, et al. miR-339 promotes development of stem cell leukemia/lymphoma syndrome via downregulation of the BCL2L11 and BAX pro-apoptotic genes. Cancer Res. 2018;78(13):3522-3531.

16. Liu Y, Huang X, Timani KA, Broxmeyer HE, He JJ. MicroRNA-124 Targets Tip110 Expression and Regulates Hematopoiesis. Stem Cells Dev. 2015;24(17):2009-2017.

17. Lind EF, Elford AR, Ohashi PS. Micro-RNA 155 is required for optimal CD8+ T cell responses to acute viral and intracellular bacterial challenges. J Immunol. 2013;190(3):1210-1216.

18. Wang H, Li C, Jian Z, Ou Y, Ou J. TGF- $\beta 1$ reduces miR-29a expression to promote tumorigenicity and metastasis of cholangiocarcinoma by targeting HDAC4. PLoS One. 2015;10(10):e0136703.

19. Han Y, Meng F, Venter J, et al. miR-34a-dependent overexpression of Per1 decreases cholangiocarcinoma growth. J Hepatol. 2016;64(6): 1295-1304.

20. Liu CH, Huang Q, Jin ZY, et al. Circulating microRNA-21 as a prognostic, biological marker in cholangiocarcinoma. J Cancer Res Ther. 2018; 14(1):220-225.

21. Correa-Gallego C, Maddalo D, Doussot A, et al. Circulating plasma levels of MicroRNA-21 and MicroRNA-221 are potential diagnostic markers for primary intrahepatic cholangiocarcinoma. PLoS One. 2016;11(9):e0163699.

22. Lund AH. miR-10 in development and cancer. Cell Death Differ. 2010;17(2):209-214. 
23. Quinonez SC, Innis JW. Human HOX gene disorders. Mol Genet Metab. 2014;111(1):4-15.

24. Calin GA, Sevignani C, Dumitru CD, et al. Human microRNA genes are frequently located at fragile sites and genomic regions involved in cancers. Proc Natl Acad Sci U S A. 2004;101(9):2999-3004.

25. Gonzalez Dos Anjos L, de Almeida BC, Gomes de Almeida T, et al. Could miRNA signatures be useful for predicting uterine sarcoma and carcinosarcoma prognosis and treatment? Cancers (Basel). 2018;10(9):E315.

26. Kim C, Go EJ, Kim A. Recurrence prediction using microRNA expression in hormone receptor positive breast cancer during tamoxifen treatment. Biomarkers. Epub 2018 Aug 23.

27. Zhu Q, Gong L, Wang J, et al. miR-10b exerts oncogenic activity in human hepatocellular carcinoma cells by targeting expression of CUB and sushi multiple domains 1 (CSMD1). BMC Cancer. 2016; 16(1):806.

28. Luo L, Yu ZP, Qin H, et al. Exosomal MicroRNA-10a Is Associated with Liver Regeneration in Rats through Downregulation of EphA4. Chin Med J (Engl). 2018;131(4):454-460.

29. Tangtanatakul P, Thammasate B, Jacquet A, et al. Transcriptomic profiling in human mesangial cells using patient-derived lupus autoantibodies identified miR-10a as a potential regulator of IL8. Sci Rep. 2017;7(1):14517.

30. Luo L, Chen B, Li S, et al. Plasma miR-10a: a potential biomarker for coronary artery disease. Dis Markers. 2016;2016:3841927.

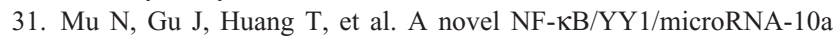
regulatory circuit in fibroblast-like synoviocytes regulates inflammation in rheumatoid arthritis. Sci Rep. 2016;6:20059.

32. Xiong G, Huang H, Feng M, et al. MiR-10a-5p targets TFAP2C to promote gemcitabine resistance in pancreatic ductal adenocarcinoma. J Exp Clin Cancer Res. 2018;37(1):76.

33. Bi L, Sun L, Jin Z, Zhang S, Shen Z. MicroRNA-10a/b are regulators of myeloid differentiation and acute myeloid leukemia. Oncol Lett. 2018; 15(4):5611-5619.

34. Haga H, Yan I, Takahashi K, Wood J, Patel T. Emerging insights into the role of microRNAs in the pathogenesis of cholangiocarcinoma. Gene Expr. 2014;16(2):93-99.

35. Tao R, Krishnan S, Bhosale PR, et al. Ablative radiotherapy doses lead to a substantial prolongation of survival in patients with inoperable intrahepatic cholangiocarcinoma: a retrospective dose response analysis. J Clin Oncol. 2016;34(3):219-226.
36. Chen X, Chen J, Liu X, Guo Z, Sun X, Zhang J. The real-time dynamic monitoring of microRNA function in cholangiocarcinoma. PLoS One. 2014;9(6):e99431.

37. Yan Y, Luo YC, Wan HY, et al. MicroRNA-10a is involved in the metastatic process by regulating Eph tyrosine kinase receptor A4-mediated epithelial-mesenchymal transition and adhesion in hepatoma cells. Hepatology. 2013;57(2):667-677.

38. Hussain N, Zhu W, Jiang C, et al. Down-regulation of miR-10a-5p promotes proliferation and restricts apoptosis via targeting T-box transcription factor 5 in inflamed synoviocytes. Biosci Rep. 2018;38(2): BSR20180003.

39. Manning BD, Toker A. AKT/PKB signaling: navigating the network. Cell. 2017;169(3):381-405.

40. Yothaisong S, Dokduang H, Techasen A, et al. Increased activation of $\mathrm{PI} 3 \mathrm{~K} / \mathrm{AKT}$ signaling pathway is associated with cholangiocarcinoma metastasis and PI3K/mTOR inhibition presents a possible therapeutic strategy. Tumour Biol. 2013;34(6):3637-3648.

41. Georgescu MM. PTEN tumor suppressor network in PI3K-Akt pathway control. Genes Cancer. 2010;1(12):1170-1177.

42. Peng Y, Croce CM. The role of MicroRNAs in human cancer. Signal Transduct Target Ther. 2016;1:15004.

43. Meng F, Henson R, Wehbe-Janek H, Ghoshal K, Jacob ST, Patel T. MicroRNA-21 regulates expression of the PTEN tumor suppressor gene in human hepatocellular cancer. Gastroenterology. 2007;133(2): 647-658.

44. Wang LJ, He CC, Sui X, et al. MiR-21 promotes intrahepatic cholangiocarcinoma proliferation and growth in vitro and in vivo by targeting PTPN14 and PTEN. Oncotarget. 2015;6(8):5932-5946.

45. Li J, Yao L, Li G, et al. miR-221 promotes epithelial-mesenchymal transition through targeting PTEN and forms a positive feedback loop with $\beta$-catenin/c-Jun signaling pathway in extra-hepatic cholangiocarcinoma. PLoS One. 2015;10(10):e0141168.

46. Zhu H, Han C, Lu D, Wu T. miR-17-92 cluster promotes cholangiocarcinoma growth: evidence for PTEN as downstream target and IL-6/ Stat3 as upstream activator. Am J Pathol. 2014;184(10):2828-2839.

47. Ji W, Sun B, Su C. Targeting microRNAs in cancer gene therapy. Genes (Basel). 2017;8(1):E21. 


\section{Supplementary material}

Table SI Predicted targets of human miR-10a-5p

\begin{tabular}{|c|c|c|}
\hline Target gene & Representative transcript & Gene name \\
\hline$B D N F$ & ENST00000439476.2 & Brain-derived neurotrophic factor \\
\hline ARSJ & ENST000003I5366.7 & Arylsulfatase family, member J \\
\hline CRLF3 & ENST00000324238.6 & Cytokine receptor-like factor 3 \\
\hline HOXАЗ & ENST00000396352.4 & Homeobox A3 \\
\hline VWC2L & ENST00000427I 24.1 & von Willebrand factor $\mathrm{C}$ domain containing protein 2-like \\
\hline RNFI86 & ENST00000375I 21.2 & Ring finger protein 186 \\
\hline SOBP & ENST000003। 7357.5 & Sine oculis binding protein homolog (Drosophila) \\
\hline TFRC & ENST00000540528.I & Transferrin receptor \\
\hline SMAPI & ENST00000370452.3 & Small ArfGAP I \\
\hline KPNA5 & ENST00000368564.I & Karyopherin alpha 5 (importin alpha 6) \\
\hline $\mathrm{HCNI}$ & ENST00000303230.4 & Hyperpolarization-activated cyclic nucleotide-gated potassium channel I \\
\hline FIGN & ENST00000333। 29.3 & Fidgetin \\
\hline DAZAPI & ENST0000033676I.6 & DAZ-associated protein I \\
\hline HOXB3 & ENST00000470495.I & Homeobox B3 \\
\hline NR6Al & ENST00000487099.2 & Nuclear receptor subfamily 6 , group $A$, member I \\
\hline KLHL29 & ENST00000486442.I & Kelch-like family member 29 \\
\hline NCOR2 & ENST0000040520I.I & Nuclear receptor corepressor 2 \\
\hline ERGIC2 & ENST00000360I50.4 & ERGIC and golgi 2 \\
\hline ELOVL2 & ENST00000354666.3 & ELOVL fatty acid elongase 2 \\
\hline USP46 & ENST0000044I 222.3 & Ubiquitin-specific peptidase 46 \\
\hline RPRDIA & ENST00000399022.4 & Regulation of nuclear pre-mRNA domain containing IA \\
\hline FLJ20373 & ENST000004I4004.2 & \\
\hline SDCl & ENST0000025435I.4 & Syndecan I \\
\hline KCNA6 & ENST00000433855.I & Potassium voltage-gated channel, shaker-related subfamily, member 6 \\
\hline CADM2 & ENST00000383699.3 & Cell adhesion molecule 2 \\
\hline FLRT2 & ENST00000330753.4 & Fibronectin leucine-rich transmembrane protein 2 \\
\hline LIXIL & ENST00000369308.3 & LixI homolog (mouse)-like \\
\hline$R O R B$ & ENST00000376896.3 & RAR-related orphan receptor $B$ \\
\hline RORA & ENST00000335670.6 & RAR-related orphan receptor $A$ \\
\hline CYTHI & ENST00000585509.I & Cytohesin I \\
\hline SMTNL2 & ENST00000338859.4 & Smoothelin-like 2 \\
\hline GOLGA3 & ENST00000204726.3 & Golgin A3 \\
\hline ATCAY & ENST00000450849.2 & Ataxia, cerebellar, Cayman type \\
\hline MAP3K7 & ENST00000369325.3 & Mitogen-activated protein kinase kinase kinase 7 \\
\hline UBE2I & ENST00000355803.4 & Ubiquitin-conjugating enzyme E2I \\
\hline TMEM $/ 83 \mathrm{~A}$ & ENST00000367242.3 & Transmembrane protein $183 \mathrm{~A}$ \\
\hline$E R I 3$ & ENST00000372259.5 & ERII exoribonuclease family member 3 \\
\hline ATXN2 & ENST00000550104.I & Ataxin 2 \\
\hline$X R N I$ & ENST0000026495I.4 & $5^{\prime}-3^{\prime}$ exoribonuclease I \\
\hline$\angle R R C 8 B$ & ENST00000330947.2 & Leucine-rich repeat containing 8 family, member B \\
\hline GABRB2 & ENST00000393959.I & Gamma-aminobutyric acid (GABA) A receptor, beta 2 \\
\hline CNNM4 & ENST00000540067.I & Cyclin M4 \\
\hline ILIRAPLI & ENST00000378993.I & Interleukin I receptor accessory protein-like I \\
\hline ZMYNDII & ENST0000038I59I.I & Zinc finger, MYND-type containing II \\
\hline IGDCC4 & ENST00000352385.2 & Immunoglobulin superfamily, DCC subclass, member 4 \\
\hline ALPL & ENST00000374840.3 & Alkaline phosphatase, liver/bone/kidney \\
\hline KLF7 & ENST000004230I5.I & Kruppel-like factor 7 (ubiquitous) \\
\hline NPAS3 & ENST00000346562.2 & Neuronal PAS domain protein 3 \\
\hline CECR6 & ENST00000399875.I & Cat eye syndrome chromosome region, candidate 6 \\
\hline SSX2IP & ENST00000342203.3 & Synovial sarcoma, $X$ breakpoint 2 interacting protein \\
\hline ZNF367 & ENST00000375256.4 & Zinc finger protein 367 \\
\hline E2F7 & ENST000004I6496.2 & E2F transcription factor 7 \\
\hline CELF2 & ENST0000037926I.4 & CUGBP, Elav-like family member 2 \\
\hline SNXI8 & ENST000003430I7.6 & Sorting nexin 18 \\
\hline ONECUTI & ENST00000560699.2 & One cut homeobox I \\
\hline
\end{tabular}


Table SI (Continued)

\begin{tabular}{|c|c|c|}
\hline Target gene & Representative transcript & Gene name \\
\hline CTD-2267D/9.3 & ENST00000578774.I & Uncharacterized protein \\
\hline PRKAA2 & ENST0000037I 244.4 & Protein kinase, AMP-activated, alpha 2 catalytic subunit \\
\hline ELOVL6 & ENST00000394607.3 & ELOVL fatty acid elongase 6 \\
\hline $\mathrm{H} 3 \mathrm{~F} 3 \mathrm{C}$ & ENST00000340398.3 & $\mathrm{H} 3$ histone, family $3 \mathrm{C}$ \\
\hline H3F3B & ENST00000591890.I & $\mathrm{H} 3$ histone, family $3 \mathrm{~B}(\mathrm{H} 3.3 \mathrm{~B})$ \\
\hline ESRRG & ENST0000036I525.3 & Estrogen-related receptor gamma \\
\hline$B A Z I B$ & ENST00000339594.4 & Bromodomain adjacent to zinc finger domain, IB \\
\hline FNBPIL & ENST00000370253.2 & Formin binding protein I-like \\
\hline PAPD5 & ENST00000357464.3 & PAP-associated domain containing 5 \\
\hline TBX5 & ENST00000349716.5 & T-box 5 \\
\hline CSRNP3 & ENST000003। 4499.7 & Cysteine-serine-rich nuclear protein 3 \\
\hline$B B X$ & ENST000004I5I49.2 & Bobby sox homolog (Drosophila) \\
\hline FAMI96A & ENST0000052278I.I & Family with sequence similarity 196, member A \\
\hline PRRT3 & ENST000004I $2055 . I$ & Proline-rich transmembrane protein 3 \\
\hline IGSFI & ENST00000370900.I & Immunoglobulin superfamily, member I \\
\hline ACTGI & ENST00000331925.2 & Actin, gamma I \\
\hline EPHA2 & ENST00000358432.5 & EPH receptor $\mathrm{A} 2$ \\
\hline KIAA0247 & ENST00000342745.4 & KIAA0247 \\
\hline MDGA2 & ENST00000439988.3 & MAM domain-containing glycosylphosphatidylinositol anchor protein 2 \\
\hline HNRNPK & ENST0000037628I.4 & Heterogeneous nuclear ribonucleoprotein $\mathrm{K}$ \\
\hline JARID2 & ENST0000034I 776.2 & Jumonji, AT-rich interactive domain 2 \\
\hline KCTDI6 & ENST00000507359.3 & Potassium channel tetramerization domain containing 16 \\
\hline PALM2 & ENST00000448454.2 & Paralemmin 2 \\
\hline WWC2 & ENST00000403733.3 & WW and $C 2$ domain containing 2 \\
\hline NR4A3 & ENST00000330847.I & Nuclear receptor subfamily 4 , group A, member 3 \\
\hline NEDD4 & ENST00000338963.2 & $\begin{array}{l}\text { Neural precursor cell expressed, developmentally downregulated 4, E3 ubiquitin protein } \\
\text { ligase }\end{array}$ \\
\hline$B C L 6$ & ENST00000406870.2 & B-cell CLL/lymphoma 6 \\
\hline$R P 6-24 A 23.6$ & ENST00000563887.I & Uncharacterized protein \\
\hline CTNNBIPI & ENST00000377263.I & Catenin, beta-interacting protein I \\
\hline WBPII & ENST0000026II67.2 & WW domain binding protein II \\
\hline TRIM2 & ENST00000338700.5 & Tripartite motif containing 2 \\
\hline ZFAND5 & ENST00000237937.3 & Zinc finger, ANI-type domain 5 \\
\hline ANXA7 & ENST00000372921.5 & Annexin A7 \\
\hline CAMK2B & ENST00000457475.I & Calcium/calmodulin-dependent protein kinase II beta \\
\hline MTMR3 & ENST00000333027.3 & Myotubularin-related protein 3 \\
\hline CTDSPL & ENST00000443503.2 & $\begin{array}{l}\text { CTD (carboxy-terminal domain, RNA polymerase II, polypeptide A) small } \\
\text { phosphatase-like }\end{array}$ \\
\hline EPHA5 & ENST00000273854.3 & EPH receptor A5 \\
\hline SVOP & ENST00000299134.5 & SV2-related protein homolog (rat) \\
\hline ST6GALNAC6 & ENST00000373I46.I & $\begin{array}{l}\text { ST6 (alpha- } \mathrm{N} \text {-acetyl-neuraminyl-2,3-beta-galactosyl-1,3)-N-acetylgalactosaminide } \\
\text { alpha-2,6-sialyltransferase } 6\end{array}$ \\
\hline RYBP & ENST00000477973.2 & RINGI and YYI binding protein \\
\hline ELAVL2 & ENST00000380II 0.4 & ELAV like neuron-specific RNA-binding protein 2 \\
\hline KIAAI 429 & ENST00000437/99.I & KIAAI429 \\
\hline $\mathrm{NR} 2 \mathrm{C2}$ & ENST0000042524I.I & Nuclear receptor subfamily 2 , group C, member 2 \\
\hline TMEMI67B & ENST00000338272.8 & Transmembrane protein I67B \\
\hline KLHDCIO & ENST00000335420.5 & Kelch domain containing 10 \\
\hline GATA3 & ENST00000379328.3 & GATA-binding protein 3 \\
\hline PRRI5L & ENST00000300557.2 & Proline-rich I5-like \\
\hline SH3D 19 & ENST00000409598.4 & $\mathrm{SH} 3$ domain containing 19 \\
\hline ITSNI & ENST00000379960.5 & Intersectin I (SH3 domain protein) \\
\hline CLASP2 & ENST0000053998I.I & Cytoplasmic linker-associated protein 2 \\
\hline FXR2 & ENST00000250II 3.7 & Fragile $X$ mental retardation, autosomal homolog 2 \\
\hline ANKFYI & ENST0000034I657.4 & Ankyrin repeat and FYVE domain containing I \\
\hline E2F3 & ENST00000346618.3 & E2F transcription factor 3 \\
\hline$S N X 12$ & ENST00000374274.3 & Sorting nexin 12 \\
\hline
\end{tabular}


Table SI (Continued)

\begin{tabular}{|c|c|c|}
\hline Target gene & Representative transcript & Gene name \\
\hline MTF2 & ENST00000370298.4 & Metal response element binding transcription factor 2 \\
\hline SERTAD 4 & ENST000003670I2.3 & SERTA domain containing 4 \\
\hline TMEM / 68 & ENST000003 I $28 \mid 4.6$ & Transmembrane protein 168 \\
\hline SHANK3 & ENST000004I 4786.2 & $\mathrm{SH} 3$ and multiple ankyrin repeat domains 3 \\
\hline ZNF280C & ENST00000370978.4 & Zinc finger protein $280 \mathrm{C}$ \\
\hline HOXAI & ENST00000355633.5 & Homeobox Al \\
\hline PDE7A & ENST0000040I827.3 & Phosphodiesterase 7A \\
\hline DPF2 & ENST000005284I6.I & D4, zinc and double PHD fingers family 2 \\
\hline CDK6 & ENST00000265734.4 & Cyclin-dependent kinase 6 \\
\hline CRK & ENST00000398970.5 & v-crk avian sarcoma virus CTIO oncogene homolog \\
\hline EBF2 & ENST00000535548.I & Early B-cell factor 2 \\
\hline LPHNI & ENST00000340736.6 & Latrophilin I \\
\hline$T B C I D 22 B$ & ENST0000037349I.3 & TBCI domain family, member 22B \\
\hline NFIX & ENST00000360I05.4 & Nuclear factor I/X (CCAAT-binding transcription factor) \\
\hline$B L Z F I$ & ENST00000367808.3 & Basic leucine zipper nuclear factor I \\
\hline CBX5 & ENST00000209875.4 & Chromobox homolog 5 \\
\hline CCNK & ENST00000389879.5 & Cyclin K \\
\hline$P D E / 2$ & ENST000003।II 80.8 & Phosphodiesterase 12 \\
\hline FAM76A & ENST00000373954.6 & Family with sequence similarity 76 , member $A$ \\
\hline BMP2K & ENST000003350I6.5 & BMP2 inducible kinase \\
\hline GPCPDI & ENST00000379019.4 & Glycerophosphocholine phosphodiesterase GDEI homolog (S. cerevisiae) \\
\hline MTFI & ENST00000373036.4 & Metal-regulatory transcription factor I \\
\hline MAPЗK $/ 3$ & ENST00000448876.I & Mitogen-activated protein kinase kinase kinase 13 \\
\hline ANKI & ENST00000289734.7 & Ankyrin I, erythrocytic \\
\hline PTEN & ENST0000037/953.3 & Phosphatase and tensin homolog \\
\hline MANEAL & ENST0000039763I.3 & Mannosidase, endo-alpha-like \\
\hline LANCLI & ENST000004433 I4.I & LanC lantibiotic synthetase component C-like I (bacterial) \\
\hline SLC6A5 & ENST00000525748.I & Solute carrier family 6 (neurotransmitter transporter), member 5 \\
\hline$A R I H 2$ & ENST0000035640I.4 & Ariadne RBR E3 ubiquitin protein ligase 2 \\
\hline FOSL2 & ENST00000379619.1 & FOS-like antigen 2 \\
\hline NR5A2 & ENST00000367362.3 & Nuclear receptor subfamily 5 , group $A$, member 2 \\
\hline TRIM66 & ENST00000299550.6 & Tripartite motif containing 66 \\
\hline GPR6I & ENST00000527748.I & G protein-coupled receptor 61 \\
\hline KLC2 & ENST00000394065.2 & Kinesin light chain 2 \\
\hline MAPKBPI & ENST00000457542.2 & Mitogen-activated protein kinase binding protein I \\
\hline$B A Z 2 B$ & ENST00000392782.I & Bromodomain adjacent to zinc finger domain, $2 \mathrm{~B}$ \\
\hline FBX030 & ENST0000023728I.4 & F-box protein 30 \\
\hline SLC38A2 & ENST00000256689.5 & Solute carrier family 38 , member 2 \\
\hline NUP50 & ENST00000347635.4 & Nucleoporin 50 kDa \\
\hline PEAI5 & ENST00000360472.4 & Phosphoprotein enriched in astrocytes 15 \\
\hline TSPAN9 & ENST0000053797I.I & Tetraspanin 9 \\
\hline CREBI & ENST00000432329.2 & cAMP responsive element binding protein I \\
\hline GCLM & ENST00000370238.3 & Glutamate-cysteine ligase, modifier subunit \\
\hline AAKI & ENST00000409085.4 & AP2 associated kinase I \\
\hline$A R R D C 3$ & ENST00000265I 38.3 & Arrestin domain containing 3 \\
\hline SRSFI & ENST00000258962.4 & Serine/arginine-rich splicing factor I \\
\hline CNOT4 & ENST0000054I284.I & CCR4-NOT transcription complex, subunit 4 \\
\hline MTSSIL & ENST00000338779.6 & Metastasis suppressor I-like \\
\hline PDE4A & ENST00000380702.2 & Phosphodiesterase 4A, cAMP-specific \\
\hline PEX5L & ENST00000467460.I & Peroxisomal biogenesis factor 5 -like \\
\hline IFFO2 & ENST00000455833.2 & Intermediate filament family orphan 2 \\
\hline KIAA/462 & ENST00000375377.I & KIAAI 462 \\
\hline NFE2LI & ENST0000058529I.I & Nuclear factor, erythroid 2-like I \\
\hline MYTIL & ENST00000399161.2 & Myelin transcription factor I-like \\
\hline MIEFI & ENST0000032530I.2 & Mitochondrial elongation factor I \\
\hline NCOA6 & ENST00000374796.2 & Nuclear receptor coactivator 6 \\
\hline RNFI80 & ENST00000389100.4 & Ring finger protein 180 \\
\hline
\end{tabular}


Table SI (Continued)

\begin{tabular}{|c|c|c|}
\hline Target gene & Representative transcript & Gene name \\
\hline FRS2 & ENST00000550389.I & Fibroblast growth factor receptor substrate 2 \\
\hline RASAL2 & ENST00000448I50.3 & RAS protein activator like 2 \\
\hline TENM2 & ENST000005I9204.I & Teneurin transmembrane protein 2 \\
\hline ZNF608 & ENST00000504926.I & Zinc finger protein 608 \\
\hline FZD2 & ENST000003I5323.3 & Frizzled family receptor 2 \\
\hline$A R H G E F / 2$ & ENST00000397843.2 & Rho guanine nucleotide exchange factor (GEF) 12 \\
\hline MYCBP & ENST00000397572.2 & MYC binding protein \\
\hline $\mathrm{BACH} 2$ & ENST00000257749.4 & BTB and CNC homology I, basic leucine zipper transcription factor 2 \\
\hline MLLT6 & ENST000003257।8.7 & $\begin{array}{l}\text { Myeloid/lymphoid or mixed-lineage leukemia (trithorax homolog, Drosophila); } \\
\text { translocated to, } 6\end{array}$ \\
\hline$T B L I X$ & ENST00000407597.2 & Transducin (beta)-like IX-linked \\
\hline ATF2 & ENST00000487334.2 & Activating transcription factor 2 \\
\hline GINS2 & ENST00000253462.3 & GINS complex subunit 2 (Psf2 homolog) \\
\hline FLTI & ENST00000282397.4 & fms-related tyrosine kinase I \\
\hline CEP85L & ENST0000036849I.3 & Centrosomal protein $85 \mathrm{kDa}$-like \\
\hline BEND3 & ENST00000369042.I & BEN domain containing 3 \\
\hline SPAG9 & ENST000002620I3.7 & Sperm-associated antigen 9 \\
\hline KCTD I 7 & ENST00000402077.3 & Potassium channel tetramerization domain containing 17 \\
\hline USF2 & ENST00000594064.I & Upstream transcription factor 2, c-fos interacting \\
\hline LGALSL & ENST00000409537.2 & Lectin, galactoside-binding-like \\
\hline TPP2 & ENST00000376052.3 & Tripeptidyl peptidase II \\
\hline DLGAP2 & ENST0000042I627.2 & Discs, large (Drosophila) homolog-associated protein 2 \\
\hline TMEMI $70 B$ & ENST00000379426.I & Transmembrane protein I70B \\
\hline ZBTB43 & ENST00000449886.I & Zinc finger and BTB domain containing 43 \\
\hline L3MBTL3 & ENST000005294I0.I & I(3)mbt-like 3 (Drosophila) \\
\hline KIAAI549 & ENST00000440I72.I & KIAAI549 \\
\hline TNRC6B & ENST00000335727.9 & Trinucleotide repeat containing 6B \\
\hline SAMD $/ 4$ & ENST00000330I75.4 & Sterile alpha motif domain containing 14 \\
\hline INO80D & ENST00000403263.I & INO80 complex subunit D \\
\hline CALCR & ENST00000359558.2 & Calcitonin receptor \\
\hline TGOLN2 & ENST00000377386.3 & Trans-golgi network protein 2 \\
\hline TET2 & ENST00000545826.I & tet methylcytosine dioxygenase 2 \\
\hline SUFU & ENST00000369902.3 & Suppressor of fused homolog (Drosophila) \\
\hline FADS3 & ENST00000540820.I & Fatty acid desaturase 3 \\
\hline LEPREI & ENST00000236040.4 & Leucine proline-enriched proteoglycan (leprecan) I \\
\hline CAMK2G & ENST0000035I 293.3 & Calcium/calmodulin-dependent protein kinase II gamma \\
\hline NFAT5 & ENST00000354436.2 & Nuclear factor of activated T-cells 5 , tonicity-responsive \\
\hline MEDI & ENST0000030065I.6 & Mediator complex subunit I \\
\hline CNOT6 & ENST00000393356.I & CCR4-NOT transcription complex, subunit 6 \\
\hline$R P I \mid-766 F / 4.2$ & ENST000005। I828.I & Protein LOC285556 \\
\hline STARD 13 & ENST00000336934.5 & StAR-related lipid transfer (START) domain containing 13 \\
\hline LCOR & ENST0000037II 03.3 & Ligand-dependent nuclear receptor corepressor \\
\hline HDAC4 & ENST000003456|7.3 & Histone deacetylase 4 \\
\hline CCDC7IL & ENST00000523505.I & Coiled-coil domain containing 7I-like \\
\hline ST8SIAI & ENST00000396037.4 & ST8 alpha- $\mathrm{N}$-acetyl-neuraminide alpha-2,8-sialyltransferase I \\
\hline MBD5 & ENST00000407073.I & Methyl-CpG binding domain protein 5 \\
\hline RBMS3 & ENST00000396583.3 & RNA binding motif, single stranded interacting protein 3 \\
\hline THRA & ENST00000450525.2 & Thyroid hormone receptor, alpha \\
\hline$B C L 2 L I I$ & ENST00000393256.3 & BCL2-like II (apoptosis facilitator) \\
\hline FBXO28 & ENST00000424254.2 & F-box protein 28 \\
\hline NT5DCI & ENST000003I9550.4 & 5 -nucleotidase domain containing I \\
\hline POLR3H & ENST00000396504.2 & Polymerase (RNA) III (DNA directed) polypeptide H (22.9 kD) \\
\hline ANK3 & ENST00000280772.2 & Ankyrin 3, node of Ranvier (ankyrin G) \\
\hline$B I C D 2$ & ENST00000356884.6 & Bicaudal D homolog 2 (Drosophila) \\
\hline PAPOLA & ENST0000055747I.I & Poly $(A)$ polymerase alpha \\
\hline$Z X D C$ & ENST00000389709.3 & ZXD family zinc finger $C$ \\
\hline DLG5 & ENST00000372391.2 & Discs, large homolog 5 (Drosophila) \\
\hline
\end{tabular}


Table SI (Continued)

\begin{tabular}{|c|c|c|}
\hline Target gene & Representative transcript & Gene name \\
\hline CCDC88A & ENST00000336838.6 & Coiled-coil domain containing 88A \\
\hline LYVEI & ENST00000256I78.3 & Lymphatic vessel endothelial hyaluronan receptor I \\
\hline PURB & ENST00000395699.2 & Purine-rich element binding protein B \\
\hline GJA9 & ENST00000454994.2 & Gap junction protein, alpha 9, 59 kDa \\
\hline KCNH5 & ENST00000322893.7 & Potassium voltage-gated channel, subfamily $\mathrm{H}$ (eag-related), member 5 \\
\hline WNK3 & ENST00000375169.3 & WNK lysine deficient protein kinase 3 \\
\hline STRN & ENST00000263918.4 & Striatin, calmodulin binding protein \\
\hline UNC5B & ENST00000335350.6 & unc-5 homolog B (C. elegans) \\
\hline FKBPI5 & ENST00000238256.3 & FK506 binding protein $15,133 \mathrm{kDa}$ \\
\hline SHISA7 & ENST00000376325.4 & Shisa family member 7 \\
\hline AGO3 & ENST00000373191.4 & Argonaute RISC catalytic component 3 \\
\hline CELF6 & ENST00000287202.5 & CUGBP, Elav-like family member 6 \\
\hline MAP3K2 & ENST00000409947.I & Mitogen-activated protein kinase kinase kinase 2 \\
\hline TIAMI & ENST00000286827.3 & T-cell lymphoma invasion and metastasis I \\
\hline$S C N 3 A$ & ENST00000360093.3 & Sodium channel, voltage-gated, type III, alpha subunit \\
\hline $\mathrm{ZDHHCI} 8$ & ENST00000374I 42.4 & Zinc finger, DHHC-type containing I8 \\
\hline ONECUT2 & ENST0000049II 43.2 & One cut homeobox 2 \\
\hline SPTY2DI & ENST00000336349.5 & SPT2, Suppressor of Ty, domain containing I (S. cerevisiae) \\
\hline CHD6 & ENST00000373233.3 & Chromodomain helicase DNA binding protein 6 \\
\hline AKAP2 & ENST00000374525.I & A kinase (PRKA) anchor protein 2 \\
\hline BTRC & ENST00000370I87.3 & Beta-transducin repeat containing E3 ubiquitin protein ligase \\
\hline SMURFI & ENST00000361368.2 & SMAD-specific E3 ubiquitin protein ligase I \\
\hline EPHA4 & ENST0000028|82I.2 & $\mathrm{EPH}$ receptor $\mathrm{A} 4$ \\
\hline WDR26 & ENST000004I 4423.2 & WD repeat domain 26 \\
\hline GATAD2A & ENST000003603I5.3 & GATA zinc finger domain containing $2 \mathrm{~A}$ \\
\hline RIMS2 & ENST00000507740.I & Regulating synaptic membrane exocytosis 2 \\
\hline PURG & ENST0000047554I.I & Purine-rich element binding protein $\mathrm{G}$ \\
\hline PALM2-AKAP2 & ENST00000374530.3 & PALM2-AKAP2 read through \\
\hline NFASC & ENST0000040I399.I & Neurofascin \\
\hline ELAVL3 & ENST00000359227.3 & ELAV like neuron-specific RNA binding protein 3 \\
\hline LHFPL4 & ENST00000287585.6 & Lipoma HMGIC fusion partner-like 4 \\
\hline ARNT & ENST00000358595.5 & Aryl hydrocarbon receptor nuclear translocator \\
\hline STK35 & ENST0000038I 482.3 & Serine/threonine kinase 35 \\
\hline CEP350 & ENST00000367607.3 & Centrosomal protein $350 \mathrm{kDa}$ \\
\hline ZBTBI6 & ENST00000335953.4 & Zinc finger and BTB domain containing 16 \\
\hline NUFIP2 & ENST00000225388.4 & Nuclear fragile $X$ mental retardation protein interacting protein 2 \\
\hline CLCN5 & ENST00000376088.3 & Chloride channel, voltage-sensitive 5 \\
\hline C3orfl4 & ENST0000049448I.I & Chromosome 3 open reading frame 14 \\
\hline TFAP2A & ENST000003796|3.3 & Transcription factor AP-2 alpha (activating enhancer binding protein 2 alpha) \\
\hline CSMDI & ENST00000400I86.3 & CUB and Sushi multiple domains I \\
\hline MAPREI & ENST0000037557I.5 & Microtubule-associated protein, RP/EB family, member I \\
\hline UBXN7 & ENST00000296328.4 & UBX domain protein 7 \\
\hline WAPAL & ENST00000298767.5 & Wings apart-like homolog (Drosophila) \\
\hline SLC9A7 & ENST00000328306.4 & Solute carrier family 9, subfamily A (NHE7, cation proton antiporter 7), member 7 \\
\hline ZDHHC2I & ENST00000380916.4 & Zinc finger, DHHC-type containing 21 \\
\hline $\mathrm{RBICCI}$ & ENST00000025008.5 & RBI-inducible coiled-coil I \\
\hline DVL3 & ENST000003। $3 \mid 43.3$ & Dishevelled segment polarity protein 3 \\
\hline SMAD2 & ENST00000262160.6 & SMAD family member 2 \\
\hline MCMBP & ENST00000360003.3 & Minichromosome maintenance complex binding protein \\
\hline OTUD7A & ENST00000307050.4 & OTU domain containing 7A \\
\hline AFF4 & ENST00000265343.5 & AF4/FMR2 family, member 4 \\
\hline KCNC3 & ENST00000376959.2 & Potassium voltage-gated channel, Shaw-related subfamily, member 3 \\
\hline SLC25AI & ENST000002I 5882.5 & Solute carrier family 25 (mitochondrial carrier; citrate transporter), member I \\
\hline CI4orf28 & ENST00000325192.3 & Chromosome 14 open reading frame 28 \\
\hline SESN3 & ENST0000053644I.I & Sestrin 3 \\
\hline SCARB2 & ENST00000264896.2 & Scavenger receptor class B, member 2 \\
\hline ZNF202 & ENST00000336|39.4 & Zinc finger protein 202 \\
\hline
\end{tabular}


Table SI (Continued)

\begin{tabular}{|c|c|c|}
\hline Target gene & Representative transcript & Gene name \\
\hline SLC35GI & ENST0000037| 408.3 & Solute carrier family 35, member GI \\
\hline IRSI & ENST00000305 I 23.5 & Insulin receptor substrate I \\
\hline AHSA2 & ENST00000394457.3 & AHAI, activator of heat shock $90 \mathrm{kDa}$ protein ATPase homolog 2 (yeast) \\
\hline CADMI & ENST00000452722.3 & Cell adhesion molecule I \\
\hline HTT & ENST00000355072.5 & Huntingtin \\
\hline CNTNAP5 & ENST00000431078.I & Contactin associated protein-like 5 \\
\hline ZNF827 & ENST00000379448.4 & Zinc finger protein 827 \\
\hline $\mathrm{CDH} / 9$ & ENST00000540086.I & Cadherin 19, type 2 \\
\hline
\end{tabular}

\section{Publish your work in this journal}

OncoTargets and Therapy is an international, peer-reviewed, open access journal focusing on the pathological basis of all cancers, potential targets for therapy and treatment protocols employed to improve the management of cancer patients. The journal also focuses on the impact of management programs and new therapeutic agents and protocols on

\section{Dovepress}

patient perspectives such as quality of life, adherence and satisfaction The manuscript management system is completely online and includes a very quick and fair peer-review system, which is all easy to use. Visit http://www.dovepress.com/testimonials.php to read real quotes from published authors. 